\title{
Characterisation and selection of a Lactobacillus species to re-colonise the vagina of women with recurrent bacterial vaginosis
}

\author{
NIGEL W. MCLEAN* and ISOBEL J. ROSENSTEIN \\ Imperial College of Science, Technology and Medicine, Department of GenitoUrinary Medicine, Jefferiss \\ Research Trust Laboratories, Praed Street, London W2 1PG
}

\begin{abstract}
This paper reports the results of characterising and selecting a strain of Lactobacillus for potential use as a probiotic in regenerating the vaginal flora of women with recurrent episodes of bacterial vaginosis (BV). BV is a condition characterised by a depletion of vaginal lactobacilli accompanied by an overgrowth of a mixed vaginal flora of aerobic, anaerobic and micro-aerophilic species in very large numbers. BV has been associated with various gynaecological and obstetric complications and has an extremely high recurrence rate, due in part to the failure to establish a normal vaginal flora after antimicrobial therapy. A total of 60 vaginal isolates of lactobacilli was assessed for characteristics considered important for vaginal re-colonisation. The characteristics studied were the in-vitro inhibitory activity of the lactobacilli against bacterial species isolated from women with recurrent $\mathrm{BV}$, acid production after growth of the lactobacilli in liquid culture, production of hydrogen peroxide $\left(\mathrm{H}_{2} \mathrm{O}_{2}\right)$ and adhesiveness of the lactobacilli to exfoliated vaginal epithelial cells (VEC). Four strains of lactobacilli, $L$. acidophilus (61701 and 61880), L. crispatus (55730) and L. delbrueckii subsp. delbrueckii (65407), demonstrated the greatest inhibitory activity against the $\mathrm{BV}$-associated bacterial species. Two of these isolates (55730 and 61880) produced $\mathrm{H}_{2} \mathrm{O}_{2}$. All four isolates produced a highly acidic environment after growth in liquid medium $(\mathrm{pH}<4)$. Only one of these (strain 61701) was strongly adherent to VEC ( $>100$ bacteria/VEC). A further isolate ( $L$. acidophilus 48101) did not demonstrate maximum inhibitory activity against BV-associated bacteria, but was found to be a strong producer of $\mathrm{H}_{2} \mathrm{O}_{2}$ and was also highly adherent to VEC. Isolates 61701 and 48101 could be candidates for use as probiotics for vaginal re-colonisation.
\end{abstract}

\section{Introduction}

Bacterial vaginosis (BV) is an infection of the female genital tract characterised by a malodorous vaginal discharge, high vaginal $\mathrm{pH}$, a depletion of Lactobacillus spp. and an overgrowth of diverse aerobic, anaerobic and micro-aerophilic species such as Gardnerella vaginalis, Prevotella spp., Peptostreptococcus spp., Mycoplasma hominis, Ureaplasma urealyticum and Mobiluncus spp. in very large numbers [1]. The factors that initiate the shift in the vaginal ecology are incompletely understood. BV is widely believed to be

Received 2 July 1999; accepted 22 Sept. 1999.

Corresponding author: Dr I. Rosenstein, Scientific Programmes Division, PHLS Headquarters, 61 Colindale Ave, London NW9 5DF.

*Present address: Rowett Research Services, Greenburn Road, Bucksburn, Aberdeen AB21 9SB. the most frequently encountered vaginal infection in medical practice [2]. The prevalence varies according to the population studied. In the UK, it has been reported as $11 \%$ in a gynaecology outpatient clinic [3]. In the USA, BV was reported in $17 \%$ of women seeking gynaecological care [4], but in only $5 \%$ of women visiting a student health clinic for routine examination [5]. The prevalence of $\mathrm{BV}$ is much higher in women attending clinics for sexually transmitted diseases, e.g., it was $33 \%$ in the USA study [5].

BV has been associated with various gynaecological and obstetric complications including pelvic inflammatory disease (PID), post-caesarean delivery endometritis, chorioamnionitis and premature rupture of membranes, late miscarriage and pre-term labour [6]. A study in pregnant women demonstrated that women who were positive for BV on screening were five times more likely to experience preterm labour or late miscarriage than 
those without BV [7]. Recently, links have been demonstrated between abnormal vaginal flora, lack of lactobacilli and HIV infection [8]. Lactobacilli possess several biological characteristics which may protect against HIV infection, including the virucidal effects of hydrogen peroxide $\left(\mathrm{H}_{2} \mathrm{O}_{2}\right)$ produced by some strains [9].

Oral metronidazole is currently the recommended treatment of choice for BV. Although antibiotic therapy has been shown to eliminate $\mathrm{BV}$-associated organisms, there is an extremely high recurrence rate, with reports of up to $50 \%$ of patients experiencing recurrent infections. Evidence points towards recurrence occurring as a result of failure to establish a normal flora following antimicrobial therapy [10]. A healthy lactobacilli-dominated vaginal flora is now considered to be of utmost importance for preventing various urogenital infections, including recurrent urinary tract infections and $\mathrm{BV}[11,12]$.

There have been several attempts to restore the normal vaginal flora by re-colonising with lactobacilli [13]. However, the correct choice of Lactobacillus strains has not always been used; for example, some strains used are not the predominant ones found in the normal vagina [14]. Bacterial adherence is considered to be an important first step in the colonisation of mammalian tissues. It has been demonstrated that strains of Lactobacillus isolated from yoghurt were significantly less adherent to exfoliated epithelial cells than clinical isolates [15]. It is also unclear whether the strains of Lactobacillus used in previous studies produced $\mathrm{H}_{2} \mathrm{O}_{2}$. $\mathrm{H}_{2} \mathrm{O}_{2}$-producing strains, which are thought to be inhibitory to other bacterial species, have been found significantly more frequently in women with a normal vaginal flora than in women with BV [16]. However, the proportion of $\mathrm{H}_{2} \mathrm{O}_{2}$-producing strains isolated from pregnant women with BV may be higher [17].

A previous study isolated strains of Lactobacillus from healthy female volunteers with a negative screen for all sexually transmitted diseases (including persistent viruses). The women from whom the strains were obtained had been recruited to a phase 1 study of a novel vaginal microbicide [18].

This paper reports the results of characterising 60 of these isolates and selecting those with properties that would make them ideal candidates for use as a probiotic in a clinical study of vaginal re-colonisation in women with recurrent BV.

\section{Materials and methods}

\section{Bacterial isolates}

Lactobacilli were isolated from vaginal swab samples from healthy volunteers [18] and identified to species level by the API system (50 $\mathrm{CH}$, bioMérieux). Stock cultures were stored at $-70^{\circ} \mathrm{C}$ in de Man, Rogosa,
Sharp (MRS) Broth (Oxoid) supplemented with glycerol $20 \% \mathrm{v} / \mathrm{v}$. Strains were cultured on MRS agar or in MRS broth at $37^{\circ} \mathrm{C}$ for $48 \mathrm{~h}$ in an anaerobic atmosphere $\left(\mathrm{N}_{2} 65 \%, \mathrm{H}_{2} 30 \%, \mathrm{CO}_{2} 5 \%\right)$. Reference cultures of $L$. acidophilus (4504), L. fermentum (700355), L. jensenii (13279), L. crispatus (4505), L. delbrueckii subsp. delbrueckii (8130) and L. casei subsp. rhamnosus (8824) were purchased from the National Collection of Industrial and Marine Bacteria Ltd.

Strains of G. vaginalis were isolated from vaginal swab samples from women with BV [19]. Stock cultures were stored at $-70^{\circ} \mathrm{C}$ in peptone-dextrose-starch broth (PDS broth) [20] supplemented with glycerol $20 \%$. Strains were cultured on PDS agar at $37^{\circ} \mathrm{C}$ for $48 \mathrm{~h}$ in an anaerobic atmosphere.

Strains of Bacteroides spp. and Pr. bivia were isolated from vaginal swabs taken from women with BV. Bacteria were grown in Brain-Heart Infusion Broth (Difco) supplemented with yeast extract $5 \mathrm{mg} / \mathrm{ml}$, haemin $5 \mu \mathrm{g} / \mathrm{ml}$ and menadione $0.2 \mu \mathrm{g} / \mathrm{ml}, \mathrm{pH} 7.4$, at $37^{\circ} \mathrm{C}$ for $48 \mathrm{~h}$ in an anaerobic atmosphere [21].

\section{$\mathrm{H}_{2} \mathrm{O}_{2}$ production}

Lactobacilli were assessed for their ability to produce $\mathrm{H}_{2} \mathrm{O}_{2}$ in a semi-quantitative assay as described previously [22]. Briefly, lactobacilli were cultured on MRS agar containing tetramethylbenzidine (Sigma) $0.25 \mathrm{mg} / \mathrm{ml}$ and horseradish peroxidase (Sigma) $0.01 \mathrm{mg} / \mathrm{ml}$ at $37^{\circ} \mathrm{C}$ for $48 \mathrm{~h}$ under anaerobic conditions. Upon exposure to air, colonies producing $\mathrm{H}_{2} \mathrm{O}_{2}$ appeared blue. The time taken for the appearance of the blue colouration was recorded and used as an indication of the quantity of $\mathrm{H}_{2} \mathrm{O}_{2}$ produced [17].

\section{Acid production}

The amount of acids produced by the lactobacilli was indirectly determined by measuring the $\mathrm{pH}$ of the culture supernate with a $\mathrm{pH}$ meter (Titrator TTT2).

\section{Deferred antagonism well assay}

A deferred antagonism well assay was used to measure the degree of inhibition of growth of G. vaginalis, Pr. bivia and Bacteroides spp. (indicator organisms) by the lactobacilli, as described previously [19]. Briefly, lactobacillus culture filtrate $(400 \mu \mathrm{l})$ was added to $16-$ $\mathrm{mm}$ diameter wells cut in freshly poured agar containing $1 \times 10^{7} \mathrm{cfu}$ of indicator organisms $/ \mathrm{ml}$. Plates were incubated anaerobically at $37^{\circ} \mathrm{C}$ for $48 \mathrm{~h}$, after which the inhibition zone radii were measured from the outer edges of the well to the edge of bacterial growth.

\section{Preparation of vaginal epithelial cells (VEC)}

VEC were collected from healthy donors by gently scraping the vaginal mucosa with a sterile cotton swab. 
The cells were dislodged from the swabs by immersing and agitating them in sterile $0.04 \mathrm{M}$ citric acid$\mathrm{Na}_{2} \mathrm{HPO}_{4}$ buffer, $\mathrm{pH}$ 4.5. They were then pelleted by centrifugation ( $800 \mathrm{~g}$ for $4 \mathrm{~min}$ ), washed twice in the same buffer and resuspended to a concentration of $1 \times 10^{6} \mathrm{VEC} / \mathrm{ml}$. The cells were stored at $4^{\circ} \mathrm{C}$ on ice until required. VEC were obtained from six donors with the following $\mathrm{ABO}$ and Rhesus blood groups: $\mathrm{O}$ negative (two), $\mathrm{O}$ positive (four) and A positive (one).

\section{Adhesion assay}

Lactobacilli were radiolabelled by growth in MRS broth containing [methyl, $1^{\prime}, 2^{\prime}{ }^{3} \mathrm{H}$ ]-thymidine $(120 \mathrm{Ci} / \mathrm{mmol}$, Amersham) at a concentration of $12 \mu \mathrm{Ci} / \mathrm{ml}$. Broths were incubated at $37^{\circ} \mathrm{C}$ for $24 \mathrm{~h}$. The bacteria were then harvested by centrifugation $(1500 \mathrm{~g}$ for $5 \mathrm{~min}$ ) and washed three times in $0.04 \mathrm{M}$ citric acid- $\mathrm{Na}_{2} \mathrm{HPO}_{4}$ buffer, $\mathrm{pH}$ 4.2. The pellet was resuspended in the buffer to a concentration of $5 \times 10^{8}$ bacteria $/ \mathrm{ml}$ and incubated statically at $37^{\circ} \mathrm{C}$ for $60 \mathrm{~min}$. Equal volumes of bacteria and VEC $(100 \mu \mathrm{l})$ were mixed and incubated at $37^{\circ} \mathrm{C}$ for $60 \mathrm{~min}$ with agitation $(120 \mathrm{rpm})$. After the incubation period, $5 \mathrm{ml}$ of ice-cold buffer were added to prevent any further adhesion. The suspension was filtered through a $12-\mu \mathrm{m}$ polycarbonate membrane filter (Millipore) and washed twice with $15 \mathrm{ml}$ of buffer to remove non-adherent bacteria. A $10 \mu \mathrm{l}$ sample of bacterial suspension was filtered through a $0.2 \mu \mathrm{m}$ polycarbonate membrane filter to determine the radioactivity associated with the bacterial cells. The disintegrations per minute $(\mathrm{dpm})$ associated with the filters was determined with a liquid scintillation spectrometer (Beckman LS6000 SC) and the number of bacteria adherent to each VEC was calculated. The mean and standard deviation (SD) of the results of three experiments performed in triplicate are shown.

\section{Results}

\section{Inhibition of BV-associated organisms by lactobacilli}

All 60 vaginal isolates of lactobacilli were assayed for their ability to inhibit the growth of one strain each of G. vaginalis, Bacteroides spp., and Pr. bivia (indicator bacteria). All 60 Lactobacillus isolates inhibited the growth of each of the BV-associated bacteria. The $G$. vaginalis isolate was more susceptible to inhibition by all the Lactobacillus isolates than the Bacteroides and Pr. bivia isolate (Fig. 1). The lactobacilli produced zones of inhibition of growth in the range 4.0$13.5 \mathrm{~mm}$ for $G$. vaginalis, $2.0-7.0 \mathrm{~mm}$ for Bacteroides spp. and 1.5-8.0 $\mathrm{mm}$ for Pr. bivia.

Fourteen lactobacilli that inhibited the indicator bacteria by one SD above the mean were selected for further study. These isolates were tested for their ability to inhibit several strains of $G$. vaginalis (6), Bacteroides spp. - B. fragilis (2), B. ureolyticus (1), B. uniformis (1), and B. vulgatus (1) - and Pr. bivia (4) (Figs. 2, 3 and 4 respectively). All the isolates of each of the three genera of indicator bacteria tested were inhibited to similar degrees by the lactobacilli (data not

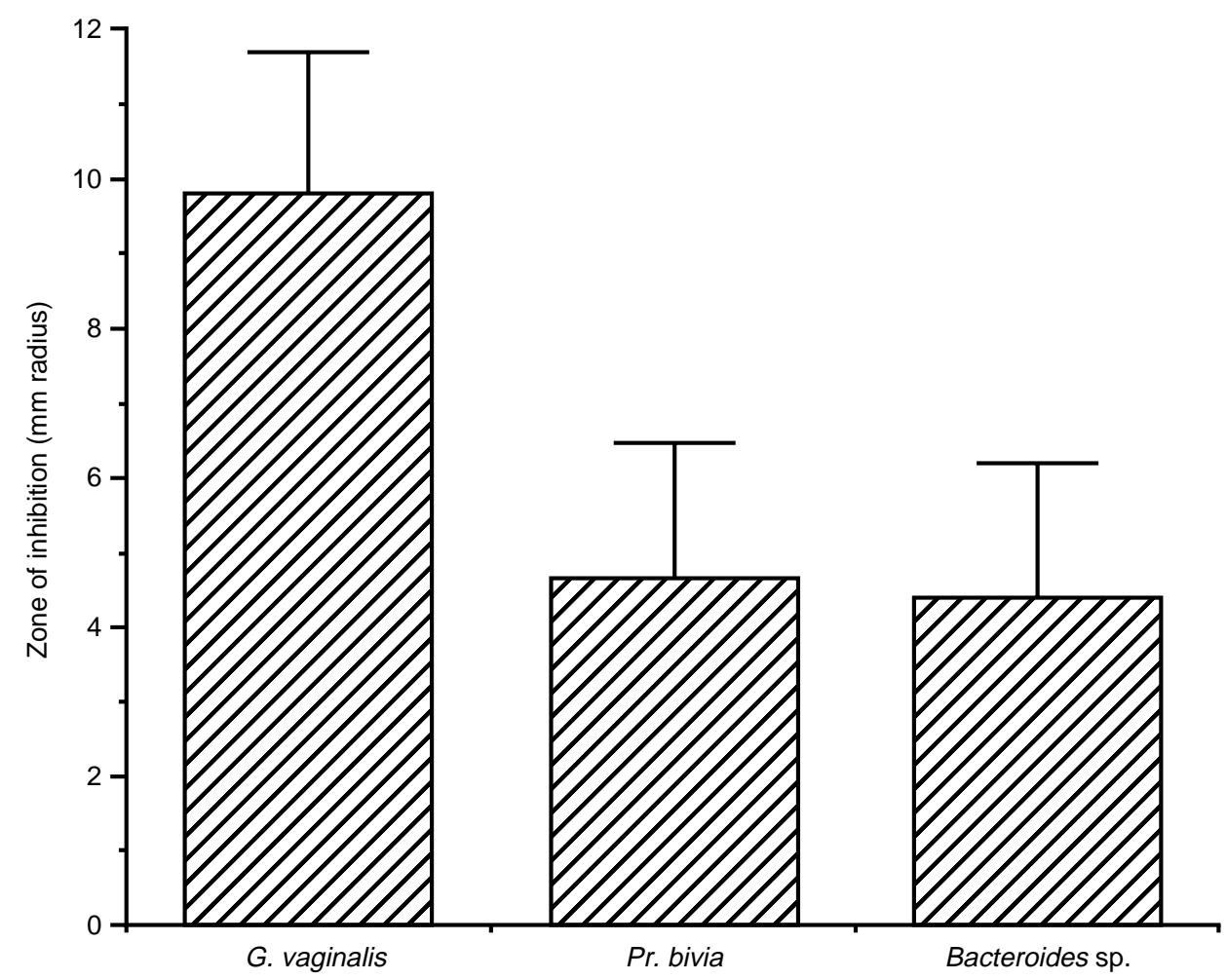

Fig. 1. Mean inhibition of BV-associated bacteria by 60 Lactobacillus isolates. 


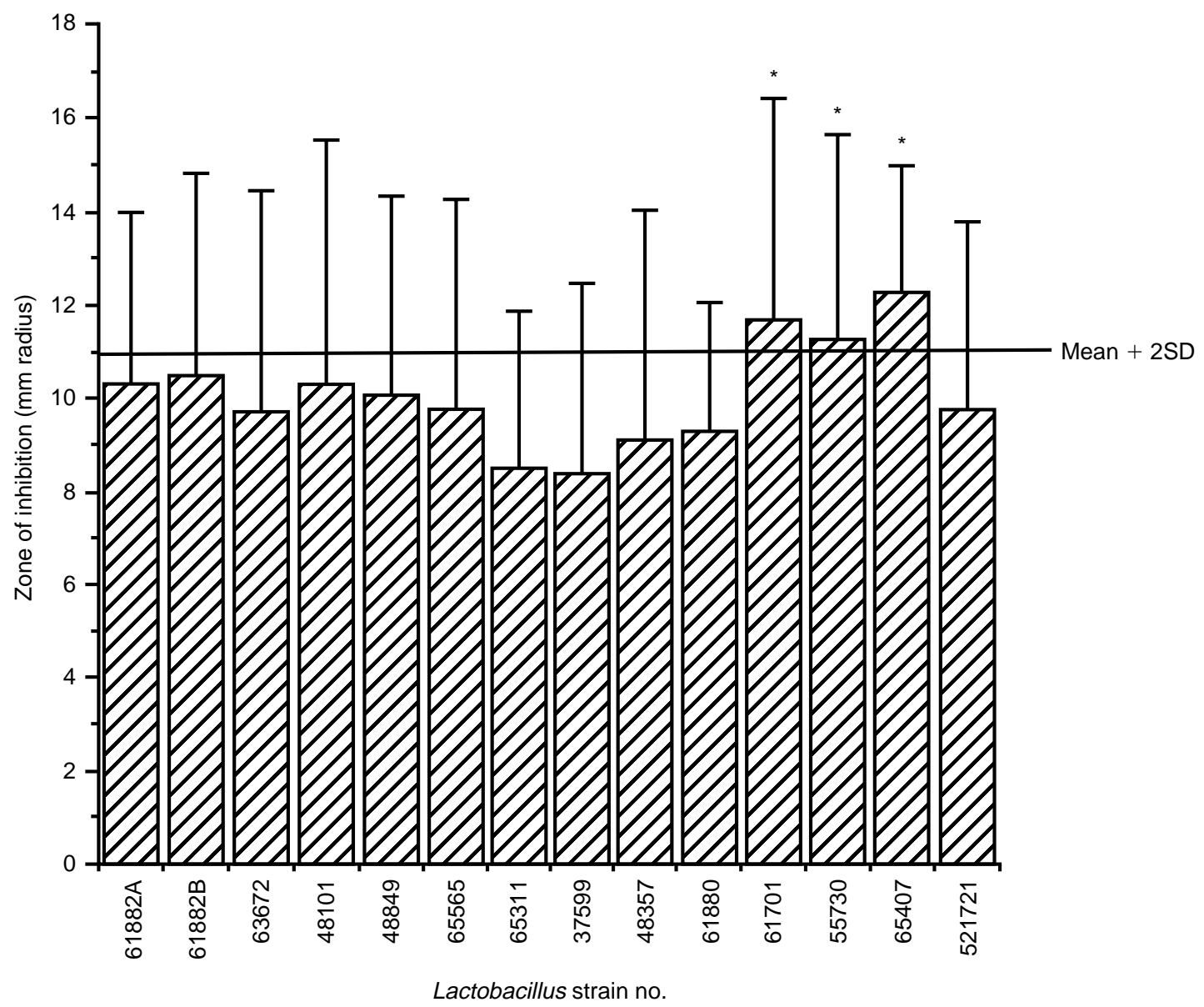

Fig. 2. Comparison of the inhibitory power of the selected lactobacilli towards G. vaginalis. ${ }^{*}$ Inhibition of G. vaginalis 2 SD above the mean.

shown). The following isolates were the most inhibitory to the growth of the indicator bacteria: L. delbrueckii subsp. delbrueckii (65407), L. crispatus (55730), L. acidophilus (61701) and L. acidophilus (61880) (2 SD above the mean).

\section{Speciation of lactobacilli}

The 14 most inhibitory isolates described above were identified to species level. Ten were identified as $L$. acidophilus, two as L. delbrueckii subsp. delbrueckii, one as L. crispatus and one as L. rhamnosus.

\section{$\mathrm{H}_{2} \mathrm{O}_{2}$ production}

The proportion of lactobacilli that produced $\mathrm{H}_{2} \mathrm{O}_{2}$ and the mean $\mathrm{pH}$ of the spent culture supernate of the lactobacilli are shown in Table 1.

\section{Adhesion of lactobacilli to VEC}

Of the 10 most potent inhibitors of BV-associated bacteria, two isolates of L. acidophilus (48101 and 61701 ) adhered in large numbers to VEC (Fig. 5). Fig. 6 shows photomicrographs of strains 48101, 61701 and 61880 adherent to VEC of a donor of blood group $\mathrm{O}^{+}$.
The majority of the surface of the VEC is covered by isolate 48101 because of the large number of bacteria adherent to the VEC and by virtue of the bacterial cell size. Controls consisting of washed VEC incubated with buffer ensured that the adherent cells were the test bacteria and not the donor's autochthonous bacteria.

All lactobacilli tested adhered in similar numbers to VEC taken between days 10 and 18 of the menstrual cycle from each of five donors, e.g., L. acidophilus 48101 adhered in the range of 30 (SD 7.3)-39 (SD 7.4) bacteria/VEC. However, each Lactobacillus strain tested adhered more avidly to VEC from the sixth donor $\left(\mathrm{O}^{+}\right)$than to VEC from the other five donors. For example, the mean adhesion of L. acidophilus 48101 to VEC from this donor, taken at five different times in the menstrual cycle was 103 (SD 37)/VEC. The ratio between strongly and weakly adherent lactobacilli was constant between VEC donors, i.e., highly adherent lactobacilli adhered in large numbers to VEC of each donor, and accordingly, weakly adherent strains were poorly adherent to VEC of all six donors.

The adhesion of lactobacilli to VEC taken from one donor of blood group $\mathrm{O}^{+}$at different stages in the menstrual cycle was tested. There was a reduction in 


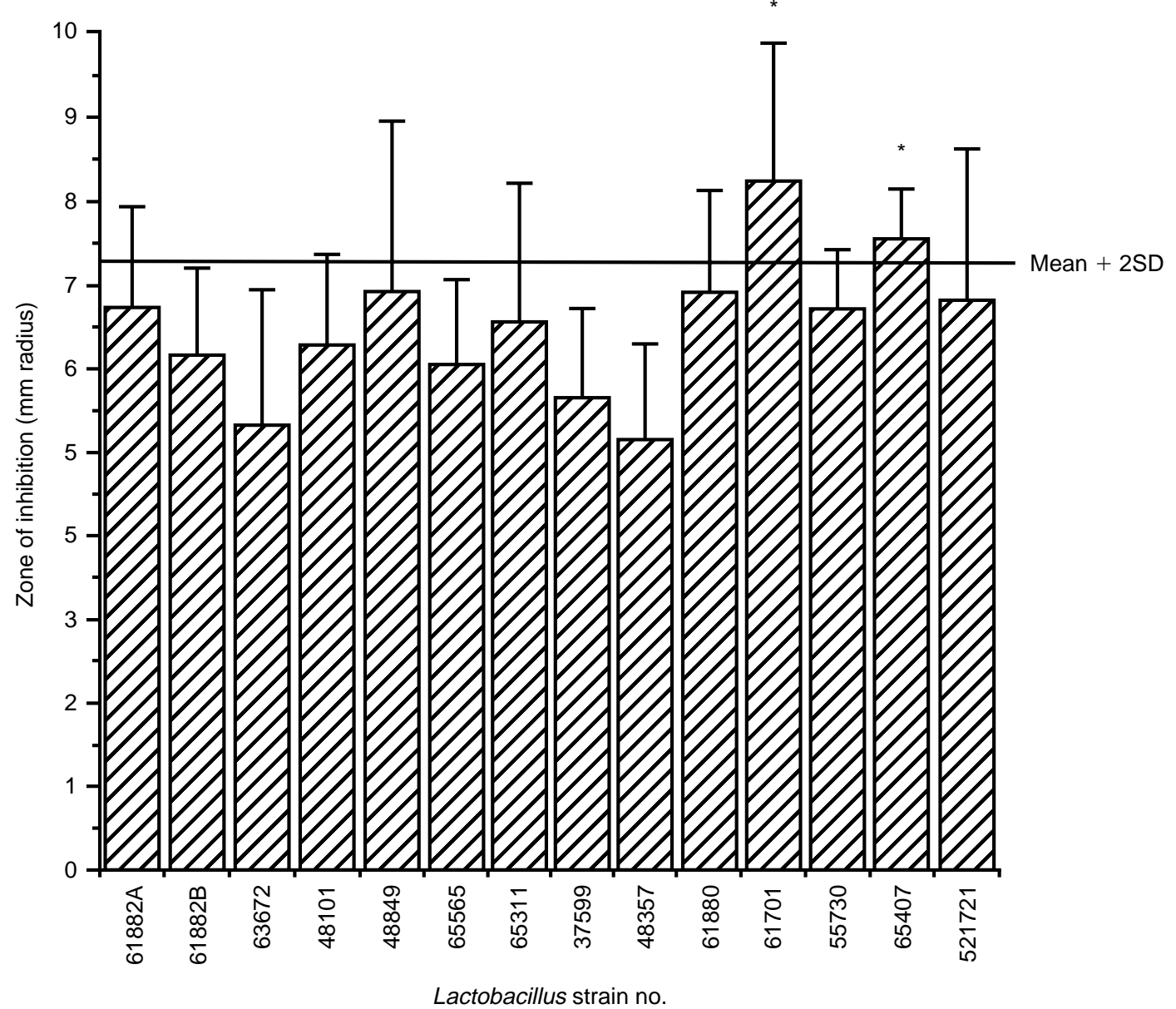

Fig. 3. Comparison of the inhibitory power of the selected lactobacilli towards Bacteroides spp. ${ }^{*}$ Inhibition of Bacteroides spp. $2 \mathrm{SD}$ above the mean.

numbers of adherent bacteria from day $12-150$ (SD 10) L. acidophilus $48101 / \mathrm{VEC}$ - to day 28 - 50 (SD 1) L. acidophilus $48101 / \mathrm{VEC}$ of the menstrual cycle. However, L. acidophilus 48101 was consistently more adherent to VEC from each donor than the other strains tested, regardless of the stage of the menstrual cycle.

The adhesion of L. acidophilus 48101 to VEC was compared with the adherence of six commercially available reference strains of lactobacilli. The clinical isolate L. acidophilus 48101 was considerably more adhesive than the reference strains (Fig. 7).

Summary of the characteristics of the Lactobacillus isolates

Table 1 summarises the inhibitory and adhesive characteristics of the Lactobacillus isolates and compares data derived from all 60 isolates with data from the 14 strains selected for further study, together with data from four strains with optimum characteristics and the fifth strongly adhesive strain (48101).

\section{Discussion}

Lactobacilli have been used as probiotics to replace the gastrointestinal flora in both man and animals [23]. Such studies have not always been stringently controlled and it has been emphasised that Lactobacillus strains with well-defined properties should be scientifically selected and characterised for specific use in commerical preparations [24]. Most of the work in this area relates to the characterisation of strains of lactobacilli for gastrointestinal use. Although lactobacilli have been used with varying degrees of success in the treatment or prevention of vaginal infections $[11,12]$, there has been little or no attempt to characterise the probiotic lactobacillus used, or to select a strain most suitable for the prevention of vaginal infections.

To our knowledge this is the first report which presents the results of characterising lactobacilli with a view to selection of an isolate with optimum characteristics for vaginal re-colonisation. A study by Andreu et al. [25] on the mechanisms of adherence of lactobacilli to vaginal epithelial cells alluded to certain adherent isolates as potential candidates for use as probiotics. 


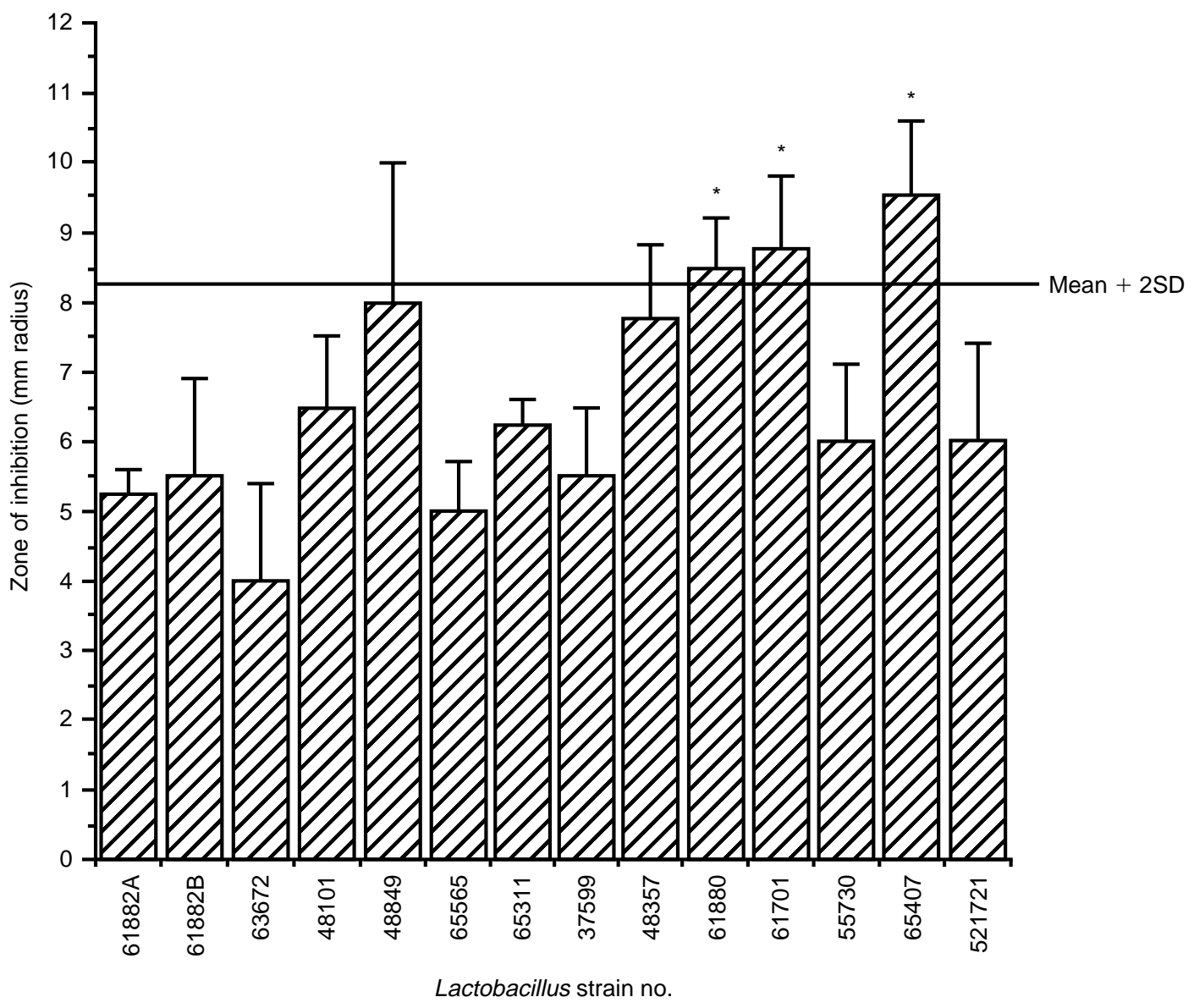

Fig. 4. Comparison of the inhibitory power of the selected lactobacilli towards Pr. bivia. *Inhibition of Pr. bivia 2 SD above the mean.

Table 1. Summary of characteristics of the Lactobacillus spp.

\begin{tabular}{llccc}
\hline Isolate & Species & Mean $\mathrm{pH}$ & $\mathrm{H}_{2} \mathrm{O}_{2}$ Production & Adhesion n/VEC \\
\hline All 60 & $\ldots$ & 4.26 & $62 \%$ & $\ldots$ \\
Selected 14 & $\ldots$ & 4.04 & $50 \%$ & $\ldots$ \\
Selected 4 & $\ldots$ & 3.86 & $50 \%$ & $\ldots$ \\
65407 & L. delb & 3.78 & - & 4 \\
55730 & L. crisp & 3.78 & + & 12 \\
61701 & L. acid & 3.80 & - & 110 \\
61880 & L. acid & 4.08 & + & 9 \\
48101 & L. acid & 4.00 & ++ & 93 \\
\hline
\end{tabular}

L. delb, L. delbrueckii subsp. delbreuckii; L. crisp, L. crispatus; L. acid, L. acidophilus; -, nonproducer of $\mathrm{H}_{2} \mathrm{O}_{2} ;+$, weak producer of $\mathrm{H}_{2} \mathrm{O}_{2} ;++$, strong producer of $\mathrm{H}_{2} \mathrm{O}_{2}$.

For the purposes of this study, four characteristics were chosen which were considered to be important for vaginal colonisation and competitive exclusion of bacteria associated with BV. Two isolates from the collection of 60 vaginal lactobacilli that showed the optimal combination of these four features were selected.

Strains were first tested for inhibitory activity against three bacterial species associated with BV. Although $\mathrm{BV}$ is a polymicrobial disease, it is acknowledged that the species associated with BV have a symbiotic relationship [26]. Thus, although the present study assessed the inhibitory activity of lactobacilli only against strains of $G$. vaginalis, Bacteroides spp. and Pr. bivia, it is likely that the inhibitory environment produced by the lactobacilli would prevent colonisation by other species associated with BV, e.g., M. hominis, which appears in large numbers only in the late and most severe stages of BV [1].

Lactic acid and other fatty acids produced by lactobacilli may contribute to the maintenance of a low vaginal $\mathrm{pH}$ and a high redox potential, which 


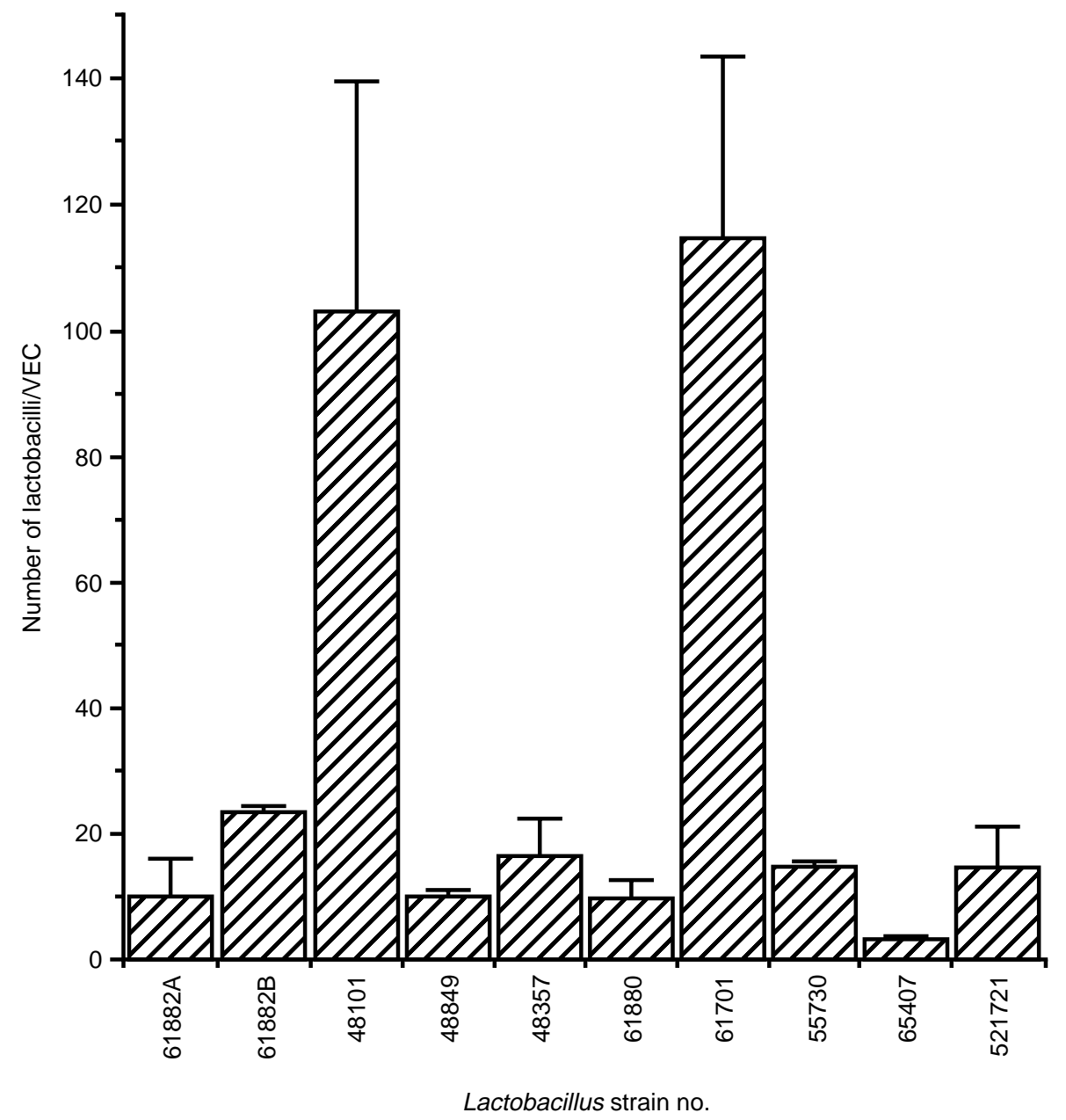

Fig. 5. Adhesion of lactobacilli to VEC from a donor of $\mathrm{ABO}$ blood group $\mathrm{O}^{+}$.

can inhibit the growth of other bacterial species [27]. The four strains of lactobacilli that demonstrated the most inhibitory activity against BV-associated bacteria were also those that produced the most acidic culture supernate after growth (a mean $\mathrm{pH}$ of 3.86 compared with a mean of 4.26 for the values from all 60 isolates). Production of $\mathrm{H}_{2} \mathrm{O}_{2}$ by lactobacilli has also been considered as important in inhibiting the overgrowth of other bacterial species in the vagina [16]. Two isolates, 61880 and 48101, were strong producers of $\mathrm{H}_{2} \mathrm{O}_{2}$. However, only one of these isolates (48101) was strongly adherent to VEC. It is essential that the Lactobacillus strain chosen for use as a vaginal probiotic should adhere well to the vaginal epithelium, to ensure continued protection. The second strongly adherent strain (61701) did not produce $\mathrm{H}_{2} \mathrm{O}_{2}$. Both the latter strains adhered well to cells derived from several donors of different blood groups and consistently to cells from the same donor at different stages of the menstrual cycle, although there was some evidence of a decrease in adherence to samples derived a few days before menstruation. There is evidence in the literature that adherence of bacteria to vaginal cells in vivo is hormonally linked, with a reduction in lactobacilli reported in the last few days of the menstrual cycle [28]. Vaginal Lactobacillus populations also vary at different stages in the life of a healthy woman, with lactobacilli present in large numbers when oestrogen levels are high (the neonatal period and during the menarche), and fall during the pre-menarchal and post-menopausal periods when oestrogen levels are low [11]. In the present study, lactobacillus adherence fell as the level of oestrogen declined towards the end of the menstrual cycle. A more detailed and extensive study is required to verify this finding.

A final consideration for the choice of probiotic should be the morphology of the bacterial cells. As the photomicrographs (Fig. 6) indicate, the morphology of the strongly adherent strains 48101 and 61701 is very different. The long cells of strain 48101 cover the epithelial cell surface more consistently than strain 61701 and may prove to be a more effective barrier to the adherence of BV-associated bacteria; strain 48101 is also a strong producer of $\mathrm{H}_{2} \mathrm{O}_{2}$. However, competitive adherence studies with these isolates together with $\mathrm{BV}$-associated bacterial species are necessary before a final choice of probiotic can be made. 

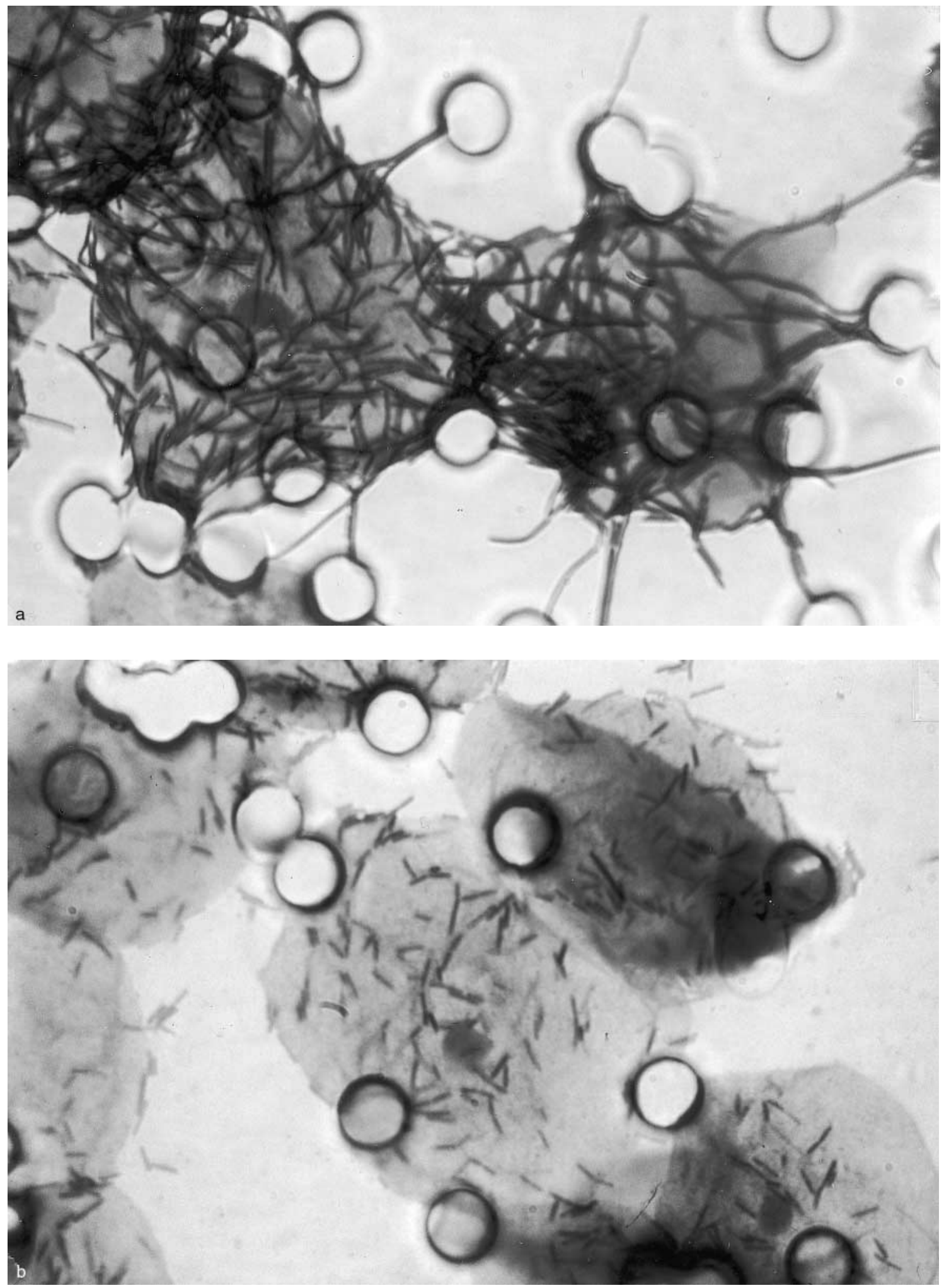

Fig. 6. Lactobacillus strains (a) 48101, (b) 61701, (c) 61880 adherent to VEC of a donor of ABO blood group $\mathrm{O}^{+}$.

The requisite for a stringent characterisation regimen for the selection of a bacterium for use as a probiotic is emphasised by the large variation in adhesion of clinical vaginal isolates of lactobacilli and reference strains isolated from various sources. It is important to consider and define the intended use of the probiotic, the source and site of isolation of the strain, and the characteristics required of the strain. The strain must be rigorously characterised by carefully designed tests in vitro before attempting expensive, statistically monitored, double-blind placebo-controlled clinical trials. 


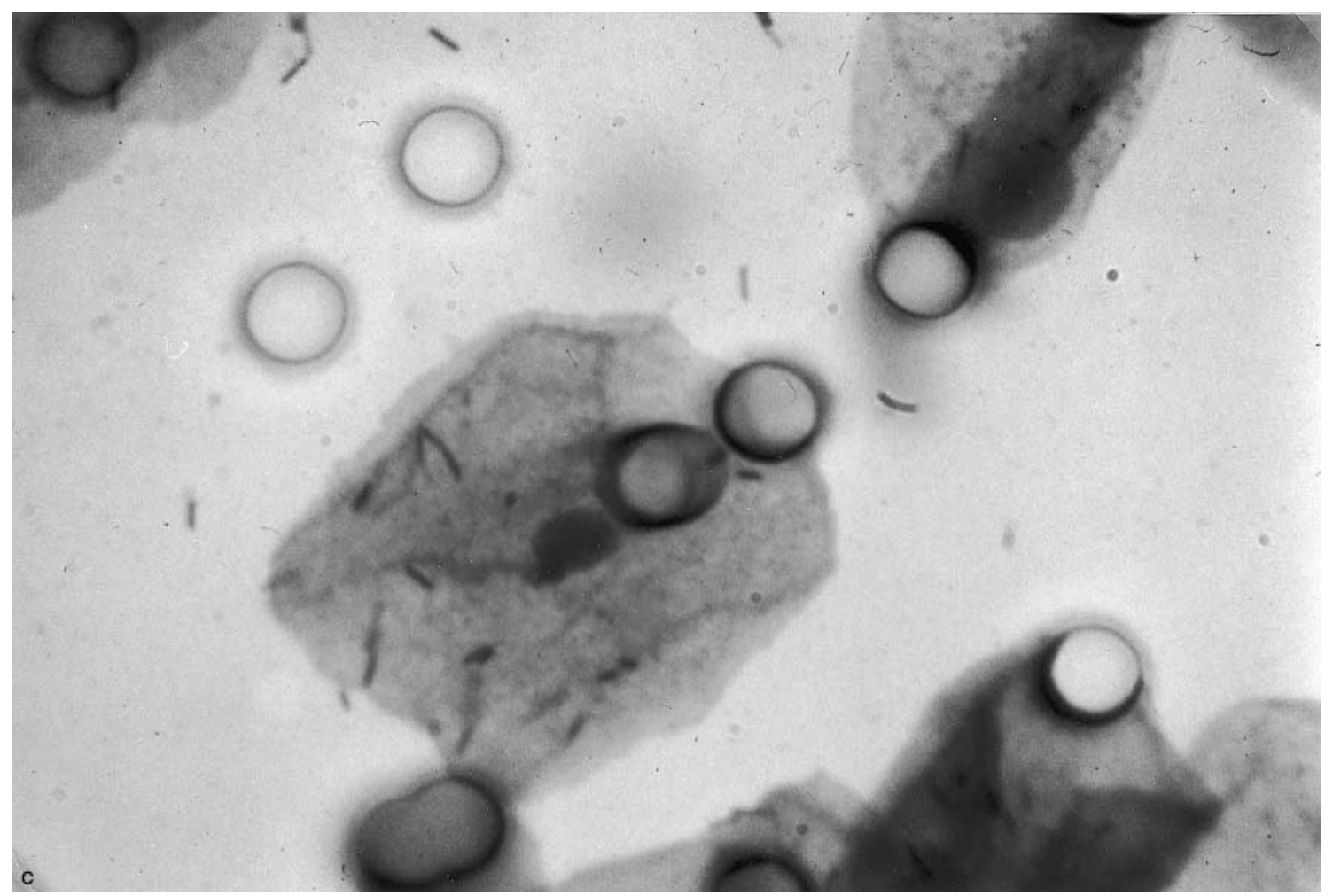

Fig. 6. (Continued).

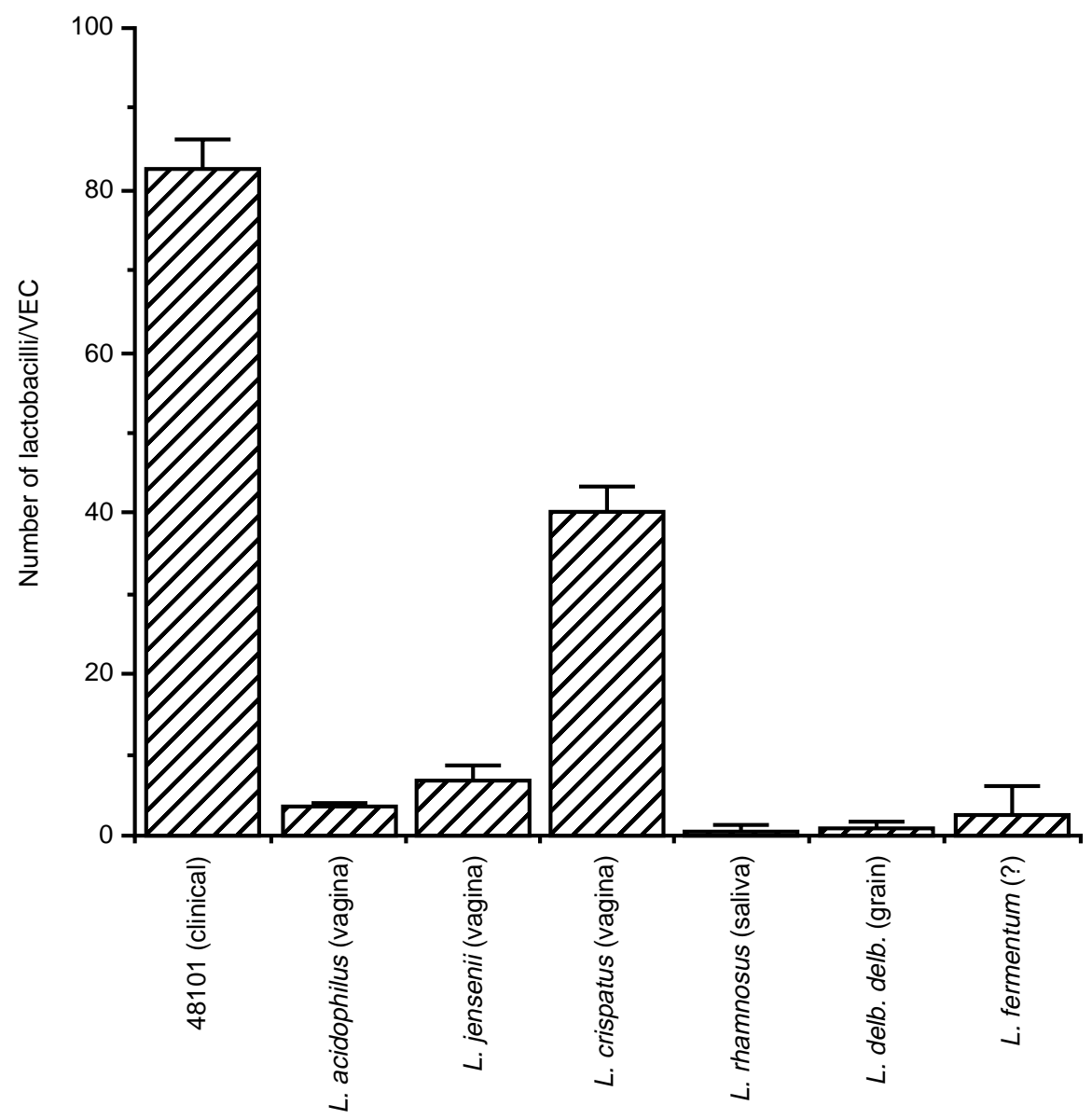

Fig. 7. Comparison of the adhesion of reference strains of lactobacilli and clinical isolate no. 48101 to VEC from a donor of blood group $\mathrm{O}^{+}$. 
The research was funded by ML Laboratories plc. We also thank the six volunteers in the department for providing high vaginal swab samples.

\section{References}

1. Rosenstein IJ, Morgan DJ, Sheehan M, Lamont RF, TaylorRobinson D. Bacterial vaginosis in pregnancy: distribution of bacterial species in different gram-stain categories of the vaginal flora. J Med Microbiol 1996; 45: 120-126.

2. Hillier S, Holmes KK. Bacterial vaginosis. In: Holmes KK, Mardh PA, Sparks PF, Wiener PJ (eds) Sexually transmitted diseases. New York, McGraw-Hill. 1990: 547-559.

3. Hay PE, Taylor-Robinson D, Lamont RF. Diagnosis of bacteria vaginosis in a gynaecology clinic. Br J Obstet Gynaecol 1992; 99: $63-66$.

4. Berg AO, Heidrich FE, Fihn SD et al. Establishing the cause of genitourinary symptoms in women in a family practice. Comparison of clinical examination and comprehensive microbiology. JAMA 1984; 251: 620-625.

5. Eschenbach DA, Hillier S, Critchlow C, Stevens C, DeRouen T, Holmes KK. Diagnosis and clinical manifestations of bacterial vaginosis. Am J Obstet Gynecol 1988; 158: 819-828.

6. Sweet RL. New approaches for the treatment of bacterial vaginosis. Am J Obstet Gynecol 1993; 169: 479-482.

7. Hay PE, Lamont RF, Taylor-Robinson D, Morgan DJ, Ison C, Pearson J. Abnormal bacterial colonisation of the genital tract and subsequent preterm delivery and late miscarriage. $B M J$ 1994; 308: 295-298.

8. Sewankambo N, Gray RH, Wawer MJ et al. HIV-1 infection associated with abnormal vaginal flora morphology and bacterial vaginosis. Lancet 1997; 350: 546-550.

9. Klebanoff SJ, Coombs RW. Virucidal effect of Lactobacillus acidophilus on human immunodeficiency virus type-1; possible role in heterosexual transmission. $J$ Exp Med 1991; 174: 289-292.

10. Hillier SL, Lipinski C, Briselden AM, Eschenbach DA Efficacy of intravaginal $0.75 \%$ metronidazole gel for the treatment of bacterial vaginosis. Obstet Gynecol 1993; 81: 963-967.

11. McGroarty JA. Probiotic use of lactobacilli in the human female urogenital tract. FEMS Immunol Med Microbiol 1993; 6: $251-264$.

12. Rosenstein IJ. Bacterial vaginosis and the normal vaginal flora: a dynamic relationship. Clin Lab 1998; 44: 949-960.

13. Hallen A, Jarstrand C, Pahlson C. Treatment of bacterial vaginosis with lactobacilli. Sex Transm Dis 1992; 19: 146-148.

14. Hughes VL, Hillier SL. Microbiologic characteristics of Lactobacillus products used for colonization of the vagina.
Obstet Gynecol 1990; 75: 244-248.

15. Wood JR, Sweet RL, Catena A, Hadley WK, Robbie M. In vitro adherence of Lactobacillus species to vaginal epithelial cells. Am J Obstet Gynecol 1985; 153: 740-743.

16. Eschenbach DA, Davick PR, Williams BL et al. Prevalence of hydrogen peroxide-producing Lactobacillus species in normal women with bacterial vaginosis. J Clin Microbiol 1989; 27: $251-256$.

17. Rosenstein IJ, Fontaine EA, Morgan DJ, Sheehan M, Lamont RF, Taylor-Robinson D. Relationship between hydrogen peroxide-producing strains of lactobacilli and vaginosis-associated bacterial species in pregnant women. Eur $J$ Clin Microbiol Infect Dis 1997; 16: 517-522.

18. Stafford MK, Cain D, Rosenstein I et al. A placebo-controlled, double-blind prospective study in healthy female volunteers of dextrin sulphate gel. A novel potential intravaginal virucide. $J$ AIDS HR 1997; 14: 213-218.

19. McLean NW, McGroarty JA. Growth inhibition of metronidazole-susceptible and metronidazole-resistant strains of Gardnerella vaginalis by lactobacilli in vitro. Appl Environ Microbiol 1996; 62: 1089-1092.

20. Dunkleberg WE, McVeigh I. Growth requirements of Haemophilus vaginalis. Antonie Van Leeuwenhoek 1969; 35: $129-145$.

21. Sojar HT, Lee J-Y, Bedi GS, Genio RJ. Purification and characterization of a protease from Porphyromonas gingivalis capable of degrading salt-solubilized collagen. Infect Immun 1993; 61: 2369-2376.

22. McGroarty JA, Tomeczek L, Pond DG, Reid G, Bruce AW. Hydrogen peroxide production by Lactobacillus species: correlation with susceptibility to the spermicidal compound nonoxynol-9. J Infect Dis 1992; 165: 1142-1144.

23. Reid G, Bruce AW, McGroarty JA, Cheng KJ, Costerton JW. Is there a role for lactobacilli in prevention of vaginal and intestinal infections? Clin Microbiol Rev 1990; 3: 335-344.

24. Klaenhammer TR. Microbial considerations in selection and preparation of Lactobacillus strains for use as dietary adjuncts. J Dairy Sci 1982; 65: 1339-1349.

25. Andreu A, Stapleton AE, Fennell CL, Hillier SL, Stamm WE. Hemagglutination, adherence, and surface properties of vaginal Lactobacillus species. J Infect Dis 1995; 171: 1237-1243.

26. Pybus V, Onderdonk AB. Evidence for a commensal, symbiotic relationship between Gardnerella vaginalis and Prevotella bivia involving ammonia: potential significance for bacterial vaginosis. J Infect Dis 1997; 175: 406-413.

27. Holmes KK, Chen KCS, Lipinski CM, Eschenbach DA. Vaginal redox potential in bacterial vaginosis (non-specific vaginitis). J Infect Dis 1985; 152: 379-382.

28. Keane FEA, Ison CA, Taylor-Robinson D. A longitudinal study of the vaginal flora over a menstrual cycle. Int $J$ STD AIDS 1997; 8: 489-494. 